\title{
Penerapan Metode Ripple Down Rules Untuk Mendiagnosa Penyakit Hamster
}

\author{
Sri Putri Sundari \\ Program Studi Teknik Informatika, Universitas Budi Darma, Medan, Indonesia \\ Email: ${ }^{1}$ putri.sundari2001@gmail.com
}

\begin{abstract}
Abstrak
Hamster adalah salah satu dari banyak hewan yang dimiliki dan mulai diminati banyak orang. Seiring berjalannya waktu, hamster mulai dikenal sebagai binatang peliharaan. Hamaster juga rentan terhadap penyakit. Penyakit pada hamster dan gejala yang menyebabkan sangat banyak, masalahnya sekarang tidak hanya perlu diketahui penyebab penyakit tetapi yang penting adalah mengetahui dengan cepat penyakit yang diderita juga diatasi agar penyakitnya bisa diobati.Sistem pakar yang merupakan salah satu cabang dari ilmu kecerdasan buatan, yang mampu bertindak sebagai ahli dalam bidang studi tertentu, peneliti berpikir petugas kesehatan hewan untuk membantu mendiagnosis penyakit pada hamster sedini mungkin. Metode Ripple Down Rule (RDR) adalah salah satu metode yang memiliki kemampuan expert system inferensi/pencarian dan perolehan pengetahuan. Dengan menggunakan RDR suatu sistem akan dapat mengidentifikasi penyakit sebagai ahli dengan gejala klinis seperti inputannya. Sistem pakar untuk mendiagnosa penyakit pada hamster menggunakan metode Ripple Down Rules (RDR) ini bertujuan menelusuri gejala yang ditampilkan dalam bentuk pertanyaan-pertanyaan agar dapat mendiagnosa jenis penyakit yang diderita oleh hasmter, supaya mendapatkan hasil untuk penanganan dan dapat menyembuhkan penyakit hasmter.
\end{abstract}

Kata Kunci: Sistem Pakar; Penyakit; Hamster; Ripple Down Rules

\section{Abstract}

Hamsters are one of the many animals that are owned and are beginning to attract many people. Over time, hamsters began to be known as pets. Hamasters are also susceptible to disease. Diseases in hamsters and symptoms that cause very much, the problem now is not only need to know the cause of the disease but the important thing is to know quickly the disease suffered is also overcome so that the disease can be treated. Expert system which is one branch of artificial intelligence, capable of acting as experts in certain fields of study, researchers think animal health workers to help diagnose disease in hamsters as early as possible. The Ripple Down Rule (RDR) method is one method that has expert system inference / search capabilities and knowledge acquisition. By using RDR a system will be able to identify the disease as an expert with clinical symptoms such as input. The expert system for diagnosing disease in hamsters uses the Ripple Down Rules (RDR) method to explore the symptoms displayed in the form of questions in order to diagnose the type of hasmter's illness, to get results for treatment and to cure hasmter disease.

Keywords: Expert Systems; Diseases; Hamsters; Ripple Down Rules

\section{PENDAHULUAN}

Sistem pakar adalah perangkat lunak yang didesain khusus berdasarkan artificial intelegence, berfungsi untuk merekam dan menduplikasikan kemampuan pakar. Sistem pakar juga sebagai program yang berbasis pengetahuan yang menyediakan solusi-solusi dengan kualiatas pakar untuk problema-problema dalam suatu masalah [1]. Sistem pakar merupakan program yang bekerja sesuai dengan pemikiran dan pengetahuan pakar untuk menyelesaikan masalah tertentu. Dengan menggunakan sistem pakar, pemakai akan diajukan beberapa pertanyaan, kemudian pemakai memasukkan jawaban atau memilih jawaban yang ditampilkan dilayar komputer sehingga, pemakai dapat menemukan rekomendasi atau output yang harus ditempuh pemakai berdasarkan jawaban yang dipilihnya. Pada saat ini sistem pakar sangat berguna untuk memecahkan masalah yang rumit, mengambil keputusan bedasarkan pemikiran para pakaruntuk memecahan masalah bahkan sistem pakar juga dapat berguna untuk mendiagnosa berbagai penyakit[2].

Penyakit merupakan suatu gangguan kesehatan pada tubuh yang dapat merubah metabolisme tubuh sehingga menyebabkan ketidaknyamanan dari penderita. Penyakit hewan adalah gangguan kesehatan pada hewan yang antara lain, disebabkan oleh cacat genetik, proses degeneratif, gangguan metabolisme, trauma, keracunan, infestasi parasit, dan infeksi mikroorganisme patogen seperti virus, bakteri, cendawan, dan rickettsia. Hamster merupakan salah satu dari sekian banyak binatang peliharaan yang mulai diminati banyak orang. Seiring berjalannya waktu, hamster mulai dikenal sebagai binatang peliharaan. Wajah hamster yang lucu dan menggemaskan membuat banyak orang terpikat. Selain itu, memelihara hamster juga memerlukan usaha yang sangat minimal. Karena banyaknya pecinta hamster, hamster tidak lepas dari hama dan penyakit yang menyerangnya. Perkembangan hamster akan terganggu dan tidak produktif jika terkena suatu penyakit. Untuk itu para pecinta hamster harus rajin meneliti kondisi hamster agar jika terserang suatu penyakit atau diserang hama dapat segera diatasi. Jenis-jenis penyakit hamster diantaranya yaitu flu, diare, ekor basah, gangguan pernapasan, dan kutu kulit.

Kematian seekor hamster akibat terserang penyakit akan menimbulkan kerugian ekonomi, mengingat harga hamster yang cukup mahal. Selain itu hamster juga sering terkena penyakit dapat menyebabkan pemelihara harus benar-benar merawah hewan peliharaannya, seperti membersihkan kandang dan membersihkan bulu-bulu hamster tersebut. Kunci dalam perawatan hamster adalah pada pemberian makanan yang teratur, bergizi, serta sesuai 
kesukaan. Selain itu harus dijaga kebersihan makanan, tempat makan, dan lingkungan kandang secara umum. Sangkar/kandang harus terhindar dari gangguan binatang lain, seperti ular, dan kucing yang selain bisa jadi predator juga dapat membawa penyakit.

Di era modern seperti sekarang hampir setiap orang/rumah memiliki akses internet, untuk membantu para pemilik hamster mengetahui kondisi kesehatan hamster mereka, maka dibuatlah sebuah sistem pakar secara terkomputerisasi yang dapat membantu para pemilik hamster untuk mengetahui kondisi kesehatan hamster. Nantinya para pemilik hamster dapat mengetahui kondisi kesehatan hamster mereka secara optimal, dengan cara mencari tahu menggunakan sistem pakar tersebut.

Dalam perancangan pembangunan aplikasi ini akan digunakan metode Ripple Down Rules untuk mengolah data-data gejala penyakit hamster yang nantinya akan menghasilkan output berupa data rekomendasi untuk pecinta hamster. Perancangan ini menggunakan metode Ripple Down Rules dikarenakan metode ini merupakan suatu strategi pengambilan keputusan yang dimulai dari bagian premis (fakta) menuju konsklusi (kesimpulan akhir) dan metode tersebut juga mengambil keputusan berdasarkan pemikiran para pakar.

\section{METODE PENELITIAN}

\subsection{Sistem Pakar}

Sistem Pakar adalah sistem informasi yang mengadopsi pengetahuan manusia atau pakar ke dalam komputer yang dirancang untuk dapat menyelesaikan permasalahan seperti layaknya seorang pakar sehingga dapat digunakan untuk konsultasi. Pengetahuan dari pakar di dalam sistem ini digunakan sebagai dasar oleh Sistem Pakar untuk menjawab pertanyaan (konsultasi) [1], [3]-[5]. Dengan sistem pakar orang awam dapat menyelesaikan masalahnya atau hanya sekedar mencari suatu informasi berkualitas yang sebenarnya hanya dapat diperoleh dengan bantuan para ahli di bidangnya. Sistem pakar ini juga akan dapat membantu aktivitas para pakar layaknya sebagai asisten yang berpengalaman dan mempunyai pengetahuan yang dibutuhkan oleh para konsultasi.

\subsection{Hamster}

Hamster merupakan binatang sejenis hewan pengerat, terdapat berbagai jenis di dunia dan hampir ada di tiap negara. Bentuknya yang kecil membuat hamster mudah untuk dibawa ke mana-mana dan tidak memerlukan kandang yang terlalu besar untuk merawatnya. Hamster termasuk ke dalam subfamili Cricetinae [6].

\subsection{Ripple Down Rules}

Ripple-down rules (RDR) adalah cara mendekati akuisisi pengetahuan. Akuisisi pengetahuan mengacu pada transfer pengetahuan dari ahli manusia ke sistem berbasis pengetahuan [8]. RDR juga diciptakan untuk mengatasi permasalahan utama dari sistem pakar. RDR dapat melakukan akuisisi dengan cepat dan sederhana secara ekstrim tampa bantuan dari Knowledge Engineer. Pengguna tidak perlu menguji rule base untuk mendefinisikan rule baru. Pakar hanya perlu mendifinisikan rule baru secara benar mengklasifikasikan contoh yang diberikan dan sistem dapat menentukan dimana suatu rule harus ditempatkan dalam hirarki rulenya. Keterbatasan dari RDR adalah kekurangan dalam hal inferensi yang berdayaguna. Tidak seperti SBA yang dilengkapi dengan inferensi melalui forward chaining dan backward chaining. RDR menggunakan Depth Firs Seacrh (DFS) yang memiliki kekurangan dalam hal fleksibelitas dalam hal penjawaban pertanyaan dan penjelasan yang tumbuh dari inferensi yang berdayaguna.

Ada berbagai macam penalaran dengan model yang lengkap dan sangat konsisten, tetapi pada kenyataannya banyak permasalahan yang tidak dapat terselesaikan secara lengkap dan konsisten. Ketidak konsistenan tersebut adalah akibat adanya penambahan fakta baru. Penalaran yang seperti itu disebut dengan penalaran non monotonis. Untuk mengatasi ketidak konsistenan tersebut maka dapat menggunakan penalaran dengan teori Ripple Down Rules.

Ada berbagai struktur aturan ripple-down, misalnya aturan ripple-down klasifikasi tunggal (SCRDR), aturan ripple-down klasifikasi ganda (MCRDR), aturan ripple-down yang disarangkan (NRDR) dan ripple multiple-classification berulang-inferensi Aturan-turun (RIMCRDR). Struktur data RDR yang dijelaskan di sini adalah SCRDR, yang merupakan struktur paling sederhana.

Struktur data mirip dengan pohon keputusan. Setiap node memiliki aturan, format aturan ini adalah IF cond1 AND cond2 AND ... AND condN THEN conclusion. Cond1 adalah kondisi (evaluasi boolean), misalnya $\mathrm{A}=1$, is Greater (A, 5) dan rata-rata (A, ">", rata-rata (B)). Setiap node memiliki dua node penerus, node penerus ini terhubung ke node pendahulu dengan "ELSE" atau "EXCEPT".

\section{ANALISA DAN PEMBAHASAN}

Hamster yang terserang penyakit tentu kondisinya terlihat berbeda dari biasanya, biasanya aktif dalam kandang pada awal pagi atau akhir sore ini berbeda jika kalau sudah sakit, hamster yang sakit akan terilihat dari kondisi bulunya yang terlihat kusam dan tidak bersih. Jika hamster menunjukkan sikap yang tidak seperti biasanya 
penangkar/pemelihara harus segera memeriksa keadaan hamster yang sebenarnya. Hamster yang sakit disebabkan karena hamster sebut terserang penyakit, penyakit tersebut diakibatkan oleh beberapa faktor dan gejala yang dialamin hewan tersebut seperti dari tempat dia tinggal atau kandang dan makanan yang dimakan hamster tersebut. Pada kenyataan yang ada belum tersedia sebuah sistem yang dapat menerapkan kemampuan/pengetahuan dari seorang dokter hewan dalam melakukan diagnosis penyakit hamster. Sehingga dengan adanya sistem pakar untuk mendiagnosis penyakit pada hamster dapat memudahkan petugas klinik maupun pemilik hamster dalam melakukan diagnosis penyakit pada hamster.

Untuk itu penulis membuat suatu sistem pakar dengan metode Ripple Down Rules untuk membantu para penangkar/pemelihara dalam mendiagnosa penyakit yang diderita oleh hamster tersebut dan memberi solusi terhadap penyakit yang diderita oleh hamster. Semoga dengan adanya aplikasi sistem pakar ini bisa membantu pemelihara/penangkar dalam mendiagnosa penyakit yang dialami oleh hamster.

\subsection{Penerapan Metode Ripple Down Rule}

Dalam menerapkan metode Ripple Down Rules digunakanlah representasi pengetahuan. Representasi pengetahuan merupakan metode yang digunakan untuk mendapatkan pengetahuan dalam sebuah sistem pakar yang berbasis pengetahuan (knowledge base). Basis pengetahuan mengandung pengetahuan untukpemahaman dan merupakan inti dari sistem pakar, yaitu beberapa representasi pengetahuan dari pakar yang tersusun atas dua elemen dasar yaitu fakta dan aturan, dan mesin inferensi untuk mendiagnosa penyakit pada hamster.

Basis pengetahuan yang ada di dalam sistem pakar ini digunakan untuk menentukan proses pencarian atau menentukan kesimpulan yang diperoleh setelah pengguna melakukan interaksi dengan sistem pakar yaitu memasukkan gejala yang dialami hamster. Basis pengetahuan yang digunakan dalam sistem pakar ini terdiri dari: 1. Data Penyakit

Pada sistem pakar ini terdapat lima penyakit yang akan di diagnosa dari hasmter seperti di tunjukkan pada tabel 1.

Tabel 1. Data Penyakit

\begin{tabular}{cc}
\hline Kode & Nama Penyakit \\
\hline P01 & Flu, Pilek atau Masuk Angin (Colds) \\
P02 & Diare (Diarrhoea) \\
P03 & Ekor Basah (Wet Tail) \\
P04 & Gangguan Pernapasan (Respiratory Problems) \\
P05 & Kutu Kulit (Skin Mites) \\
\hline
\end{tabular}

2. Data Gejala

Terdapat beberapa gejala yang ada pada aplikasi sistem ini yaitu akan di tunjukkan pada tabel 2 .

Tabel 2. Data Gejala

\begin{tabular}{cl}
\hline Kode & \multicolumn{1}{c}{ Gejala } \\
\hline G01 & Hamster Sering Bersin \\
G02 & Hidung Terlihat Basah \\
G03 & Nafas Yang Terdengar Berat \\
G04 & Kotoran Berwarna Hijau \\
G05 & Kotoran Lembek \\
G06 & Kotoran Berukuran Besar \\
G07 & Area Sekitar Anus Terlihat Basah \\
G08 & Nafas Terengah-engah \\
G09 & Nafas Terlihat Pelan \\
G10 & Nafas Menimbulkan Bunyi \\
G11 & Sering Menggaruk-garuk \\
G12 & Menggesek-gesekkan tubuhnya ke kandang \\
G13 & Kulit Menjadi Merah Hingga Bulu Rontok \\
\hline
\end{tabular}

Pada sistem pakar yang penulis buat, penulis menggunakan dengan metode Ripple Down Rules, basis pengetahuan yang terbentuk berubah berdasarkan hubungan tree.Tahap pertama dalam pembangun apliaksi adalah membangun pohon data dalam sistem, yang digunakan untuk merancang rule identifikasi penyakit Hamster. Tahap pembuatan data penyimpanan digunakan database mysql Integration Services untuk proses pemuatan data. Proses pemuatan data pertama kali dilakukan pada tabel-tabel dimensi, kemudian pemuatan data dilakukan pada tabel fakta. Pembuatan data penyimpanan dilakukan sebagai yang mendasari dari database yang menyediakan sumber data untuk kubus OLAP.Tree yang terbentuk akan membentuk proses pertanyaan yang mengarah dari satu penyakit ke gejala lainnya. Penjelasan berikut ini adalah contoh pembentukan pengetahuan yang didapat dari tabel 1. 
Building of Informatics, Technology and Science (BITS)

Volume 2, No 2, December 2020 Page 71-75

ISSN 2684-8910 (media cetak)

ISSN 2685-3310 (media online)

Tabel 3. Penyakit dan Gejala

\begin{tabular}{|c|c|c|}
\hline No & $\begin{array}{c}\text { Penyakit } \\
\end{array}$ & Gejala \\
\hline 1 & Flu, Pilek atau Masuk Angin (Colds) (P01) & $\begin{array}{l}\text { Hamster Sering Bersin (G01) AND Hidung Terlihat Basah } \\
\text { (G02) AND Nafas Yang Terdengar Berat (G03) }\end{array}$ \\
\hline 2 & Diare (Diarrhoea)(P02) & $\begin{array}{l}\text { Kotoran Berwarna Hijau (G04) AND Kotoran Lembek (G05) } \\
\text { AND Kotoran Berukuran Besar (G06) }\end{array}$ \\
\hline 3 & Ekor Basah (Wet Tail) (P03) & $\begin{array}{l}\text { Diare (Diarrhoea) (P02) AND Area Sekitar Anus Terlihat } \\
\text { Basah (G07) }\end{array}$ \\
\hline 4 & $\begin{array}{l}\text { Gangguan Pernapasan } \quad \text { (Respiratory } \\
\text { Problems) (P04) }\end{array}$ & $\begin{array}{l}\text { Nafas Terengah-engah (G08) AND Nafas Terlihat Pelan (G09) } \\
\text { AND Nafas Menimbulkan Bunyi (G10) }\end{array}$ \\
\hline 5 & Kutu Kulit(Skin Mites) (P05) & $\begin{array}{l}\text { Menggaruk-garuk (G11) AND Menggesek-gesekkan tubuhnya } \\
\text { ke kandang (G12) AND Kulit Menjadi Merah Hingga Bulu } \\
\text { Rontok (G13) }\end{array}$ \\
\hline
\end{tabular}

Rule berfungsi untuk mengambil keputusan dalam mendiagnosa suatu penyakit setelah memasukkan gejala-gejala yang diderita. Adapun tabel keputusan untuk aplikasi sistem pakar ini akan di tunjukkan pada tabel 4.

Tabel 4. Tabel Keputusan Penyakit

\begin{tabular}{cccccc}
\hline Kode & $\begin{array}{c}\text { Flu, Pilek atau } \\
\text { Masuk Angin } \\
\text { (Colds) }\end{array}$ & $\begin{array}{c}\text { Diare } \\
\text { (Diarrhoea) }\end{array}$ & $\begin{array}{c}\text { Ekor Basah } \\
\text { (Wet Tail) }\end{array}$ & $\begin{array}{c}\text { Gangguan } \\
\text { Pernapasan } \\
\text { (Respiratory } \\
\text { Problems) }\end{array}$ & $\begin{array}{c}\text { Kutu Kulit } \\
\text { (Skin Mites) }\end{array}$ \\
\hline G01 & $\square$ & & & & \\
G02 & $\square$ & & & \\
G03 & $\square$ & $\square$ & $\square$ & & \\
G04 & $\square$ & $\square$ & & \\
G05 & $\square$ & & \\
G06 & & $\square$ & $\square$ & \\
G07 & & & $\square$ & \\
G08 & & & $\square$ \\
G09 & & & \\
G10 & & & \\
G11 & & & $\square$ \\
G12 & & & \\
G13 & & & \\
\hline
\end{tabular}

Dari tabel 4 dapat disimpulkan rule sebagai berikut :

1. Penyakit 1

If G01 And G02 And G03 Then Flu, Pilek atau Masuk Angin (Colds).

2. Penyakit 2

If G04 And G05 And G06 Then Diare (Diarrhoea)

3. Penyakit 3

If P02 And G07 And Then Ekor Basah

4. Penyakit 4

If G08 And G09 And G10 Then Gangguan Pernapasan (Respiratory Problems)

5. Penyakit 5

If G11 And G12 And G13 Then Kutu Kulit (Skin Mites)

\subsection{Implementasi Program}

Tampilan login berfungsi sebagai media penghubung antara admin dengan aplikasi diagnosa penyakit hamster yang dirancang oleh penulis untuk masuk ke aplikasi dan mengolah data. Adapun screenshoot gambar untuk tampilan login pada aplikasi diagnosa penyakit hamster yang telah dirancang pada penelitian ini dapat dilihat pada gambar berikut:

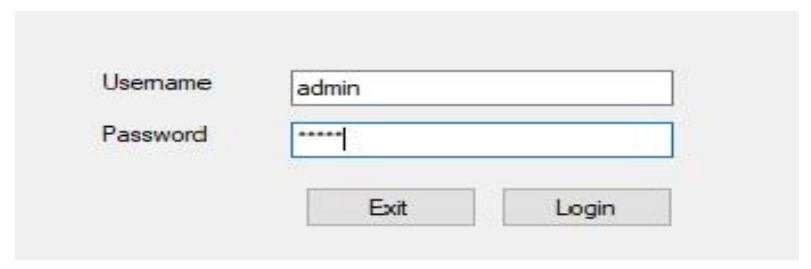

Gambar 1. Tampilan Login 
Tampilan form konsultasi berfungsi untuk menampilkan dari hasil pencarian yang dilakukan oleh user berdasarkan dari gejala-gejala yang dipilih oleh user. Adapun screenshoot gambar untuk tampilan konsultasi dapat dilihat pada gambar 2.

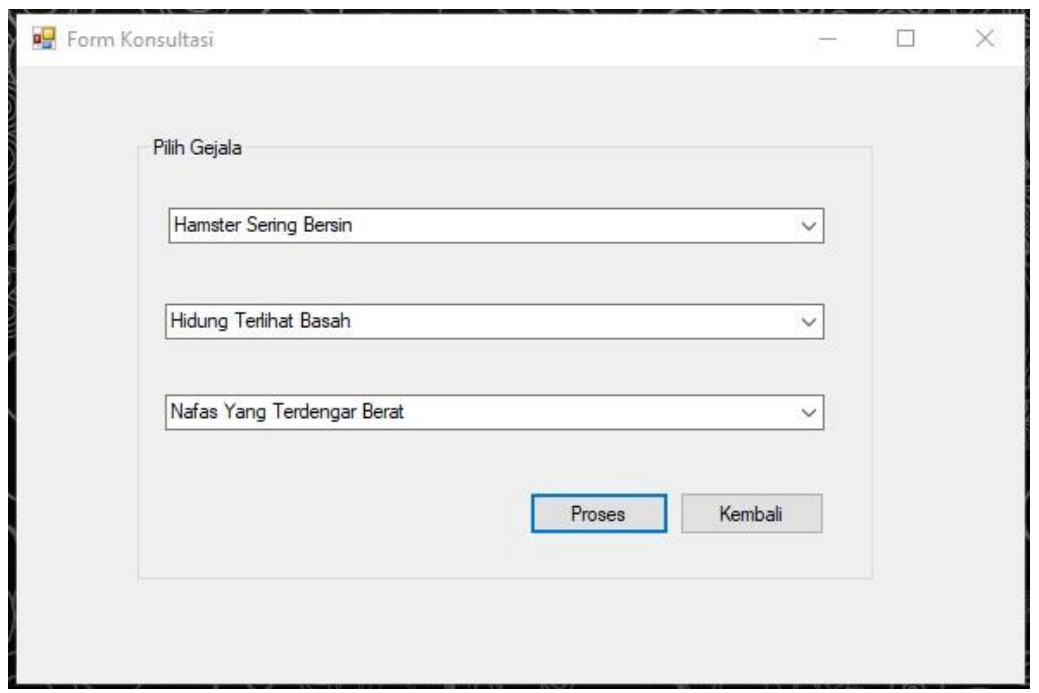

Gambar 2. Tampilan Form Konsultasi

Pada gambar 3, merupakan hasil pilihan bila gejala dari penyakit dipilih, akan menampilkan solusi penanganan dari gejala yang di derita.

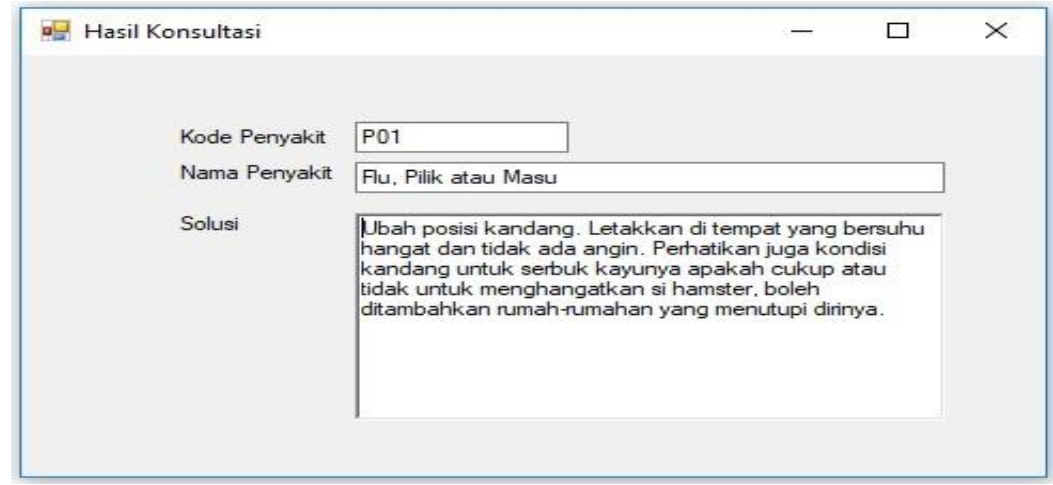

Gambar 3. Tampilan Hasil Diagnosa

\section{KESIMPULAN}

Berdasarkan hasil pembahasan, setelah melakukan diagnosa dan evaluasi sistem untuk mendiagnosa penyakit hamster dengan metode Ripple Down Rules dapat diambil kesimpulan sistem dapat mendiagnosa penyakit hamster sesuai dengan pengetahuan yang tersimpan pada database berdasarkan gejala yang dinputkan dengan hasil identifikasi berupa nama penyakit, dan solusi. Aplikasi sistem pakar ini hanya memvalidasi inputan untuk akuisisi pengetahuan berdasarkan nama penyakit dan gejala penyakit. Sistem tidak selalu update dalam menyajikan hasil diagnosa karena untuk memasukkan rule dan gejala harus masuk sebagai admin.

\section{REFERENCES}

[1] R. Efendi and I. R. Widiasari, "Perancangan Sistem Pakar Penyakit Paru-Paru Menggunakan Metode VCIRS," Metod. VCIRS, vol. 2, no. 2, pp. 291-297, 2013.

[2] M. Arhami, Konsep Dasar Sistem Pakar. Yogyakarta, 2005.

[3] P. S. Ramadhan, Mengenal Metode Sistem Pakar, 1st ed. Medan: Penerbit Uwais, 2018.

[4] Z. Azmi and V. Yasin, Pengantar Sistem Pakar Dan Metode. Surabaya: Mitra Wacana Media, 2019.

[5] Sri Hartati Sari Iswanti, Sistem Pakar dan Pengembangannya. Yogyakarta: Graha Ilmu, 2016.

[6] Wikipedia, "Hamster adalah," 2018.

[7] K. P. Kuncoro, "SISTEM PAKAR DIAGNOSIS PENYAKIT HAMSTER DENGAN."

[8] P. Compton et al., "Ripple down rules: possibilities and limitations," Proc. Sixth AAAI Knowl. Acquis. Knowledge-Based Syst. Work., pp. 1-6, 1991 . 